\title{
Super-enzyme patents get their day in court
}

David Cyranoski, Tokyo

A fierce patent battle over an enzyme widely used by biologists to create gene libraries reached its climax earlier this month.

The case, which was held in Delaware's district court in Wilmington, concluded on 11 October. A ruling that will determine whether cheaper imitations of the popular SuperScript enzyme could become more readily available is expected within the next few months.

At present, biotechnology firm Invitrogen of Carlsbad, California, has four patents associated with SuperScript, and the company dominates distribution of the enzyme in the United States.

SuperScript is a reverse transcriptase used to turn molecules of messenger RNA (mRNA), taken from cells of plants and animals, into complementary DNAs (cDNAs). These cDNAs represent all or part of a gene, and are easier to work with in the lab than mRNA. By assembling the cDNAs into libraries, researchers can study how genes express themselves, for example, during different stages of development or disease (see Nature 419,3-4;2002).

But it is hard to ensure that all of the mRNA is transcribed - especially as reverse transcriptases tend to degrade mRNA while making cDNAs. SuperScript has been refined to minimize this degradation, making it a popular and effective tool.

The Delaware court case saw Invitrogen's patents challenged by $\mathrm{BD}$ Biosciences Clontech of Palo Alto, California. During the week-long hearing, Clontech argued that the

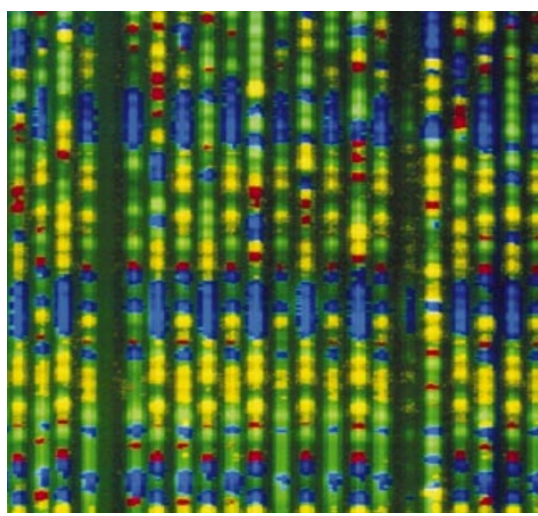

With complements: the SuperScript enzyme is used to generate cDNAs (above) for gene libraries.

patents are too narrow to cover SuperScript, that Invitrogen has misrepresented SuperScript features such as the degree to which it can reduce mRNA degradation, and that Invitrogen's protectionist strategy violates anti-trust laws. Clontech wants the judge to hit Invitrogen with massive fines - $\$ 500$ for each of the thousands of times the enzyme has been used - and to give half to Clontech as compensation.

Invitrogen officials reject all three claims but admit that the company is highly protective of SuperScript. "It is one of our core technologies," says a spokesman for the firm. Since 1996, Invitrogen has sued at least six companies, including Clontech, for reselling its reverse transcriptase or its products in violation of the purchase agreement. An initial victory in this case by Clontech, which invalidated Invitrogen's patent coverage, was successfully appealed against and the dispute continues in a separate Maryland court case.

An unfavourable ruling for Invitrogen in Delaware could set a precedent for other pending cases, such as that between the company and Stratagene of La Jolla, California. It would also open up the US market to those who have stayed out in deference to Invitrogen's patents, observers of the case say.

In addition, a ruling against Invitrogen might free up the distribution of cDNAs and cDNA-based analytical tools. This could include microarrays made using SuperScript, some of which are only available to academic researchers because of the licensing agreements that Invitrogen demands from commercial collaborators.

Biotechnology firms, such as Tokyobased Dnaform, which distributes the mouse cDNA libraries for Japan's Institute of Physical and Chemical Research (RIKEN), have complained that the terms of these agreements are too onerous. Toshizo Hayashi, Dnaform's president, claims that Invitrogen refused to grant it a licence to distribute the mouse cDNAs in the United States.

Hayashi says that no agreement has been reached and that the mouse CDNAs cannot be distributed to the United States unless an academic collaboration with RIKEN is established. But Alan Hammond, Invitrogen's patent lawyer, says that the company's protection of its patents is justified by its research efforts. "It's the cost of innovation," he says.

\section{Malta provides loophole for breast-cancer screen}

\section{Erika Check, Washington}

A Maltese biotechnology firm is set to challenge the potential monopoly on breast-cancer screening held by US company Myriad Genetics.

Synergene, which was set up in Malta in 2000, claims to have found a loophole in Myriad's patents, and says that it will launch a diagnostic test for breast cancer next January.

Myriad, which is based in Salt Lake City, Utah, owns patents on the genes BRCA1 and BRCA2, and on tests to detect mutations in these genes. Such mutations are thought to account for a sizeable number of breast-cancer cases.

But Myriad has invoked the wrath of doctors and researchers across Europe by trying to stop them from using their own tests to search for BRCA mutations.

Synergene says that Myriad's patents do not apply in Malta because the country has not signed the European Patent Convention, and Myriad has not applied for separate patents on its diagnostic tests there. Synergene will charge US $\$ 2,000$ for its new test, which will be similar to that offered by Myriad, and will be performed at Synergene's lab in Malta, says Patrick Willems, the firm's medical director.

Currently, doctors wanting to use Myriad's diagnostic tests must send samples to the company's laboratory in Salt Lake City. Alternatively, they can order similar analyses in Europe, as many labs have devised their own tests for mutations in the BRCA genes. But Willems says that he was frustrated by the European tests at his former job as a clinical geneticist at the University of Rotterdam. "We had to wait four months to get the results back," he says.

Willems adds that European labs may soon have to stop offering their home- brewed tests. European researchers, patient groups and governments have lodged formal complaints against Myriad's patents (see Nature 413, 95-96; 2001). But if their effort fails, academic labs may have to pack up their test kits.

"We will be an alternative to Myriad, even if Myriad succeeds in enforcing its patent in Europe," Willems says.

But some opponents of Myriad's patents are unimpressed. Dominique Stoppa-Lyonnet, a doctor at the Curie Institute in Paris, says that Myriad might be able to prosecute French geneticists who buy tests from Malta. And French researchers probably won't want to pay Synergene's prices, she says, even though the company will charge $\$ 760$ less than Myriad per test. "It is an interesting situation, but I am afraid it is just another way to make a lot of money," says Stoppa-Lyonnet. 